\title{
Earth sciences in the correspondence of Ferdinando Visconti
}

\author{
Vladimiro Valerio \\ Dipartimento di Storia dell'Architettura, Università IUAV, Venezia, Italy
}

\begin{abstract}
The publication of the correspondence of Ferdinando Visconti has recently brought into focus the moral and scientific importance of one of the most famous Neapolitan scientist of the 19th century. Aim of this paper is to highlight the topics related to earth sciences, programs and activities carried out in the Topographical Office and in the Academy of Science of Naples under the auspices and the direction of Ferdinando Visconti.
\end{abstract}

Key words earth sciences - biography - geodesy seismic activity - topographical survey - academy of science

\section{Biography. The first years}

On September 26th, 1847 Ferdinando Visconti, former Director of the Officio Topografico of Naples and, since 1843, General of Engineers with the charge of Inspector of the Officio Topografico and Military Institutes of Education died in Naples. His death had little resonance in the local press while the news was promptly recorded in London and in Paris; the President of the Société de Géographie, Count Louis Mathieu Molé, at the meeting on December 17 th, announced the «painful losts» of the foreign member (BSG, 1847), while the Royal Geographical Society dedicated the first issue of 1848 of its «Journal» to a short and accurate biographical portrait of the Neapolitan scientist (Journal of the Royal Geographical Society, 1848). For the deaf and marginal Neapolitan

Mailing address: Dr. Vladimiro Valerio, Dipartimento di Storia dell'Architettura, Università IUAV, Palazzo Badoer, Calle della Laca San Polo 2468, I-30125 Venezia, Italy; e-mail: vladimir@iuav.it culture of those years - we are close to the first signs of constitutional revolts of 1847-1848 one of the many generals of Bourbon Army had died, but for the employees of the Officio and for those who had the luck to know him, or simply turned to him for advice, information on scientific instruments, on methods concerning geodesy or matters related to earth science, his memory remained intact for years. With the Unity of Italy the memory of many famous people of the Neapolitan culture of the 19th century was removed, and the following anti-Bourbon rhetoric, which tended to present the South as a land of brigands or legulei, also led to the oblivion of Ferdinand Visconti $\left({ }^{1}\right)$ (fig. 1).

The publication of his correspondence has recently allowed brought into focus the moral and scientific importance of one of the leading scientists to have crossed the horizon of Neapolitan culture (Visconti, Carteggio). The collection of the «personal» correspondence numerous documents of the Officio Topografico stored in the State Archive in Naples with official correspondence by Visonti have not yet been published - has highlighted the extensive network of friendships and exchange of information in many different fields but mostly relating to matters of geography, exploration and, generally speaking, to the earth sciences. Also emerged are the efforts he made to have the in- 


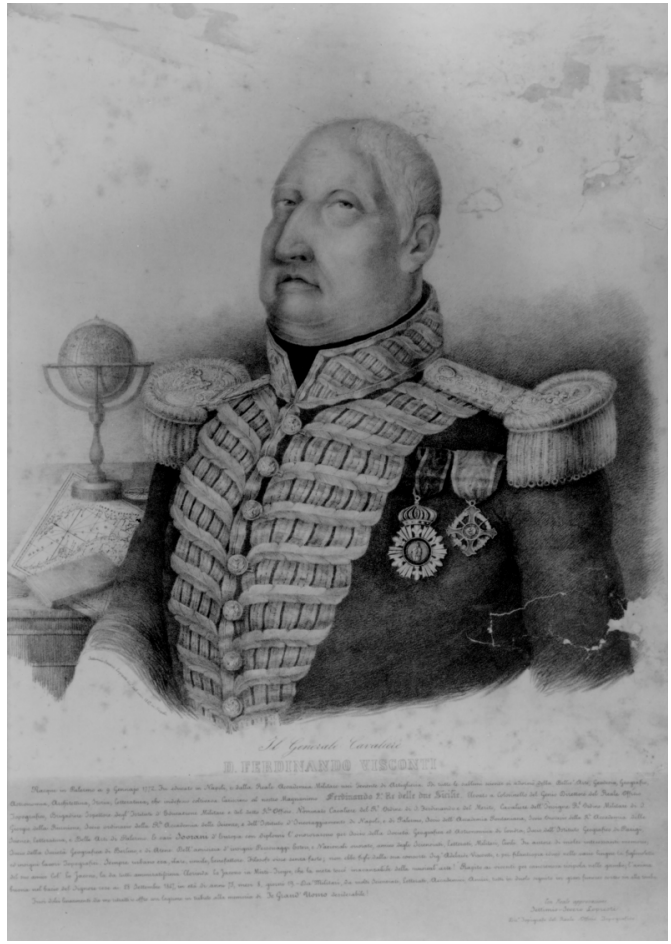

Fig. 1. Portrait of Ferdinando Visconti made in lithography by Settimio Severo Lopresti in 1847 (Private collection).

ternational level of knowledge in those fields imported into the Kingdom of Naples.

Ferdinando Visconti enjoyed the esteem of political opponents due to his rectitude and consistent behavior and his indisputable scientific authority. He always paid in person for his revolutionary ideas and, in later time, reformist ones. He was among the first and most promising students at the military school, from which came out in 1791 with the rank of lieutenant of the corps of Artillery and Engineers. But this did not save him, in 1794, from beingsentenced to ten years imprisonment in Pantelleria in a case brought against the young revolutionaries, condemned as «rei di Stato» (gulty against the State). On the island of Pantelleria he had as companions, among others, the mathematician Annibale Giordano and Francesco Fuoco future economist with whom he created a scientific cooperation and friendship that remained firm in the years to come. Freed in 1801, following the agreements of the Treaty of Florence between the French Republic and the Kingdom of Naples, Visconti failed to integrate into Neapolitan society, still shocked by the harsh Bourbon repression following the fall of the $R e$ pubblica Napoletana, despite the fact that political reintegration of convicted persons had been expressly included among the articles of Treaty and despite the protection of the Neapolitan Minister Giuseppe Zurlo.

Visconti moved to Milan, which already housed several Napolitan exiles. There he met the young Fedele Amante, future geodesist in the Topographical Officie in Naples, Francesco Macdonald (in a few years Minister of War in Naples under Murat), Giovambattista Vinci, who was to become a high officer in the Bourbon Army), Luigi Cosenz, Antonio Campana (head of the Topographical Office in Milan and Wien from 1806 until his death in 1841), the astronomer Calcedonio Casella. His life in Milan, between 1802 and 1814 was entirely spent in the learning and practice of geodetic and astronomical observations (he was a pupil and friend of the astronomer Barnaba Oriani) in topographical surveys and study of instruments and methods used in most modern geo-topographical observations and measurements. The above reconstruction of his life, though short, is essential to understand the vastness of his knowledge and his interests.

\section{Head of the Officio Topografico}

The fame gained «on the field» in Milan (he reached the level of captain and vice-director of the Deposito della Guerra) led Visconti to be recalled to his homeland in 1814, when Italian evolutionary cicle and Napoleonic dominion in Europe was coming to an end, while Naples, under Murat, remained the only Italian state not yet returned under the old regimes. The revolutionary Neapolitan dream ended a few months after his arrival in Naples (21 May 1814), but his position as Colonel Director of the Officio Topografico was not cancelled by the old Bourbon king. 


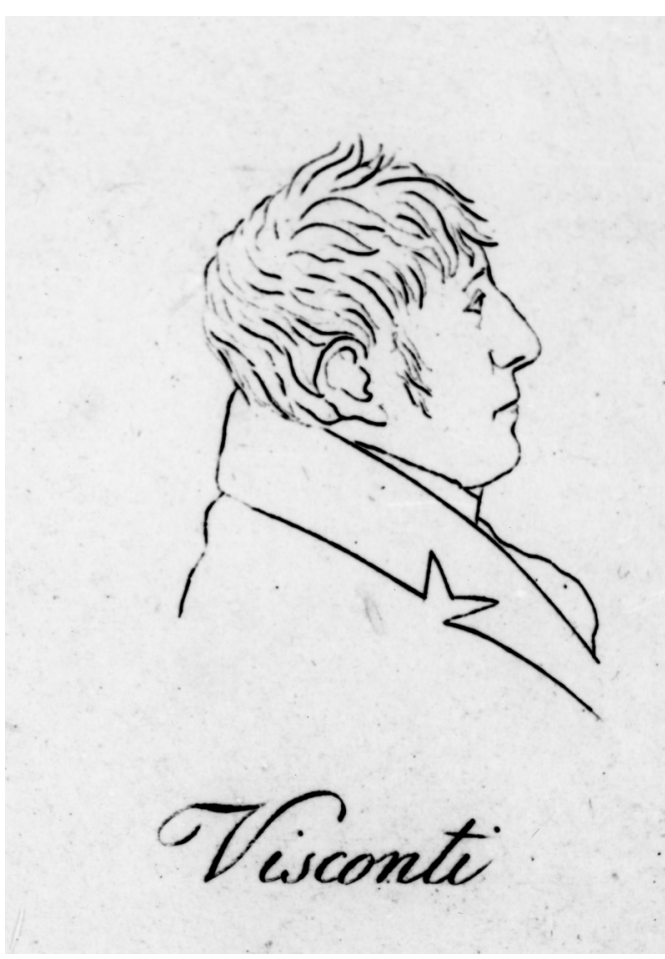

Fig. 2. Portrait of Ferdinando Visconti, taken by Giovambattista Amici with his «camera lucida» in 1817 during his stay in Naples (Biblioteca Estense di Modena, Fondo Amici, donazione eredi).

Between 1815 and 1821, Visconti laid the foundations for geodesy and military surveying in the kingdom of Naples, and not only for these disciplines: it is sufficient to think of his interest in the «camera lucida», lithography, scientific instruments and for new techniques of drawing and engraving, which led to the creation of technical schools within the Army services (for these activities see Valerio, 1995). His legacy passed the time of the Bourbon rulers and formed the geodetic Italian culture, as several employees of the Officio came to be with their ideas and their scientific and artistic capacities the core of the Italian topographical structure (fig. 2).

For the modern design and execution and for the optical instruments used Visconti's projects have survived over time, unfortunately, for

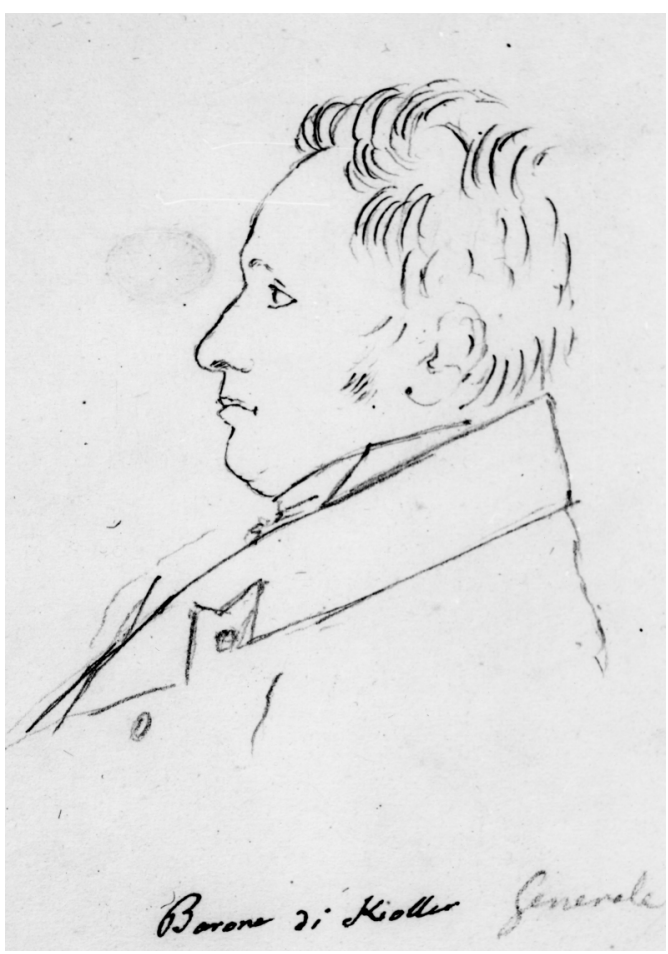

Fig. 3. Portrait of Franz Friedrich von Koller, Austrian ambassador in Naples, taken by Giovambattista Amici with his «camera lucida» in 1817 during his stay in Naples (Biblioteca Estense di Modena, Fondo Amici, donazione eredi).

the well known political and institutional reasons and for social and military events that regularly invested the Kingdom of Naples from 1821 until 1861, not all came to a completion. His projects included the study of variation in the coastline in the Phlaegrean Fields, that he rightly devised as a phenomenon related to variations of the land and not of the sea level, as discussed later.

A significant part of his correspondence ranges between the years 1818 and 1821 (28 letters), and stops suddenly as a result of his expulsion from the Officio Topografico due to his presence in the Democratic Parliament elected in 1821. Only the personal friendship and esteem of Baron Friedrich von Franz Koller (fig. 3) - Austrian Ambassador in Naples and the Commander in chief of the military forces of occupation - at 
whose residence Visconti was welcome guest (despite his revolutionary past and his sympathy for Murat) and of the Prussian Ambassador Friedrich Ramdhor, avoided a worst fate.

\section{Out of the Officio Topografico}

Between 1822 and 1830, the year of reinstatement in a military position, Visconti gained his living as an architect and expert in the Court and continued to plan and perform scientific missions as a member of the Academy of Sciences whose «permanent secretary», Teodoro Monticelli, was one of his old friends (fig. 4). On the behalf of Academy Visconti performed the survey of mineral waters and their sources on the island of Ischia.

The third decade of the century was the darkest as far as repression of all liberal spirit and the removal of any critical public functions are concerned. In 1828, the English Geologist Lyell wrote disheartened from Naples to his sister:

«Poor Costa, with several other naturalists of decidely superior knowledge to any of the present professors in the university here, have been deprived of their chairs and persecuted to beggary for their 'constitutional' opinions» (Life, Letters and Journals ..., 1881, p. 213).

Visconti, however, like other Neapolitan scientists «of decidely superior knowledge», continued to be a reference for foreign scientists visiting Naples and for those who needed information and data on geography and the nature of the Kingdom of Naples. The same Lyell, in a previous letter dated October 29th, 1828, wrote that as soon as he arrived in Naples «went straight to Colonel Visconti, the geographer who immediately put me in the way of everything» (Life, Letters and Journals..., 1881, p. 209). Among others we know that he met the mathematician Charles Babbage, in 1828, and the naturalists Robert Brown and Joseph Pentland in the next years. Visconti's friendship with the English Admiral William Henry Smyth always kept him very close to British culture, he became a member of the Royal Geographical Society and of the Royal Astronomical Society since their foundations and was correspondent and friend of Admiral Francis Beaufort, Director of the Hydrographic Office. Visconti also proved to be an excellent bridge between the Neapolitan and British cultures: when the officer of the Bourbon Navy Vincenzo Lettieri went to London to take over the pirofregate (steam frigates) «Guiscardo» and «Tancredi», built in British shipyards, he took care to introduce him to Beaufort $\left(^{2}\right)$. Contacts with the astronomer Ferdinand Rudolph Hassler of Philadelphia are in a publication by Visconti $\left(^{3}\right)$ but he had correspondence with almost all the European institutions involved in geodetic and topographical issues.

Neapolitan friends and fellows were mostly on the liberal side of society: Teodoro Monticelli, Giustino Fortunato, the geographer Ferdinand de Luca and Francesco Ricciardi, whose home in Vomero housed daily meetings of the Neapolitan intellighentia and Visconti was an assiduous frequenter.

A personality like Ferdinando Visconti, recalled in 1844 by Antonio Ulloa as a «wonderful man of European reputation» (Antologia militare,1844), leaved manifold traces in his correspondence, ranging from opinions and comments on the psychological nature of people he knew and their behavior, political-institutional observations, analysis of the instruments and their quality, reports of operations conducted in the topographic and geodetic fields in Naples and in the whole of Italy.

Some pieces of correspondence concerning the earth sciences will be briefly presented.

On the geodetic activities, in the letters those passages concerning the measurement of the base of Castelvolturno, accomplished between 1818 and 1819 are of great interest $\left(^{4}\right)$. In March 1818 we know that Visconti

«si trovava in Castelvolturno per disporre quanto bisogna per la misura d'una base geodetica da farsi colla catena di Ramsden tra Castelvolturno stesso e Patria» (Visconti, Carteggio, p. 37-38) [«was in Castelvolturno in order to put what was needed for the measurement of a geodetic base to be done with Ramsden's chain between Castelvolturno and Patria Lake»]

while in April of the same year, «la misura della base geodetica ... [lo] tiene occupatissimo e 


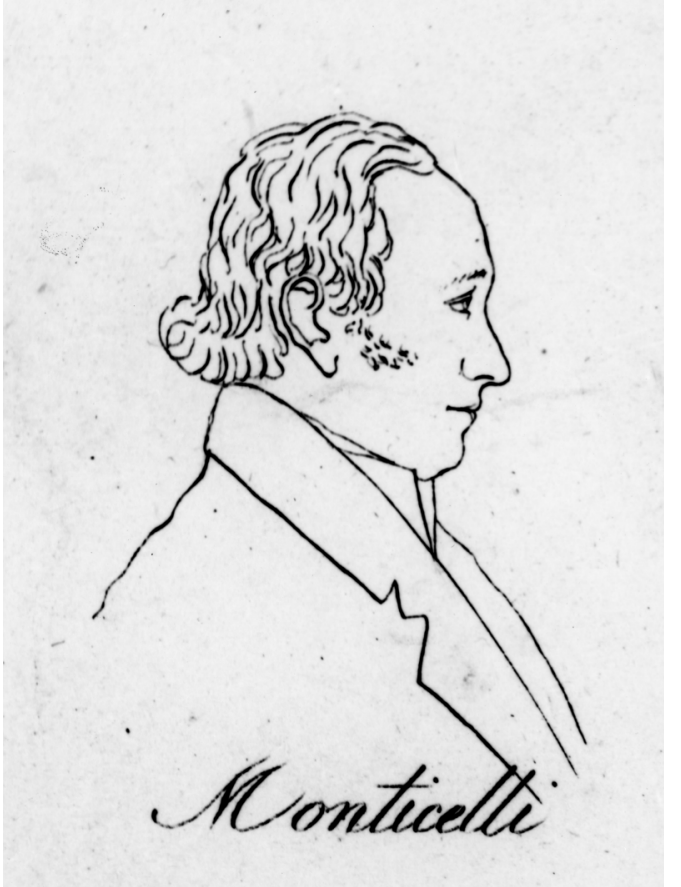

Fig. 4. Portrait of Teodoro Monticelli, secretary of the Academy of Science in Naples, taken by Giovambattista Amici with his «camera lucida» in 1817 during his stay in Naples (Biblioteca Estense di Modena, Fondo Amici, donazione eredi).

[l]'obbliga a frequenti assenze» da Napoli (Visconti, Carteggio, p. 45) [«the measure of the geodetic base [...] keeps [him] busy and forces him to frequent absences from Naples»], these and more passages in the letters make us understand the enormous amount of preparatory work for the measurement of the base something hitherto unknown - and the continuing presence of Visconti himself on the field side by side with geographers.

We also find interesting news on the measurement of an arc of parallel passing through Naples, from Ponza to Fasano in Puglia. In April 1842 Visconti informed the Secretary of the Royal Geographical Society, Julian Jackson, that:

«nel 1841 la nostra grande triangolazione è stata condotta lungo il parallelo di Napoli ad oggetto di misurare un arco di parallelo dell'estenzione di circa $4^{\circ} 1 / 2$ tra l'isola di Ponza, e Fasano nella provincia di Bari» (Visconti, Carteggio, p. 147) ( $\left(^{5}\right)$ [《in 1841 our large triangulation was conducted along the parallel of Naples with the aim of measuring an arc of parallel long about $4^{\circ} 1 / 2$ between the island of Ponza and Fasano in the province of Bari»].

\section{Moreover, Visconti states that:}

«in seguito la triangolazione sarà diretta in modo da potersi misurare un'altro arco di parallelo di $4^{\circ}$ tra l'isola di Maretimo in Sicilia e il Capo Spartivento in Calabria, come ancora un arco di meridiano di circa $5^{\circ}$ tra le isole di Tremiti e Capo Passero in Sicilia» (Visconti, Carteggio, p. 147) [«next the triangulation will be directed so that we may measure another arc of parallel of $4^{\circ}$ between the island Maretimo close to Sicily and Cape Spartivento in Calabria, as yet an arc of the meridian of about $5^{\circ}$ between the islands of Tremiti and Capo Passero in Sicily»].

In April 1842, due to the decrease of the surveyors:

«si è solo spinta innanzi la triangolazione lungo il parallelo di Napoli, terminando la porzione che rimane tra Napoli e Fasano sull'Adriatico» (Visconti, Carteggio, p. 159) [ «the triangulation was carried on only along the parallel of Naples, bringing to a completion the portion that remains between Naples and Fasano on the Adriatic Sea»].

Closely linked to the extent of the arcs of meridian parallel is the phenomenon of deviation of the plumb, which had concerned him since the early ' 1820 s and of which there is a trace in an important "Rapporto sui lavori astronomici da eseguirsi nel corso del 1827» [Report on the astronomical work to be performed in the course of 1827] read at the Academy of Sciences of Naples (Atti Reale Accademia Scienze, 1832). As happened to the astronomers of Brera in Milan, which, on completion of the Lombard extension of the arc of parallel from Bordeaux to Fiume, found a difference of about 20" between the astronomical latitudes and trigonometric ones of Milan and Parma, so Visconti registered a similar difference between the coordinates obtained by astronomical and trigonometric methods in some places of the Kingdom of Naples: 


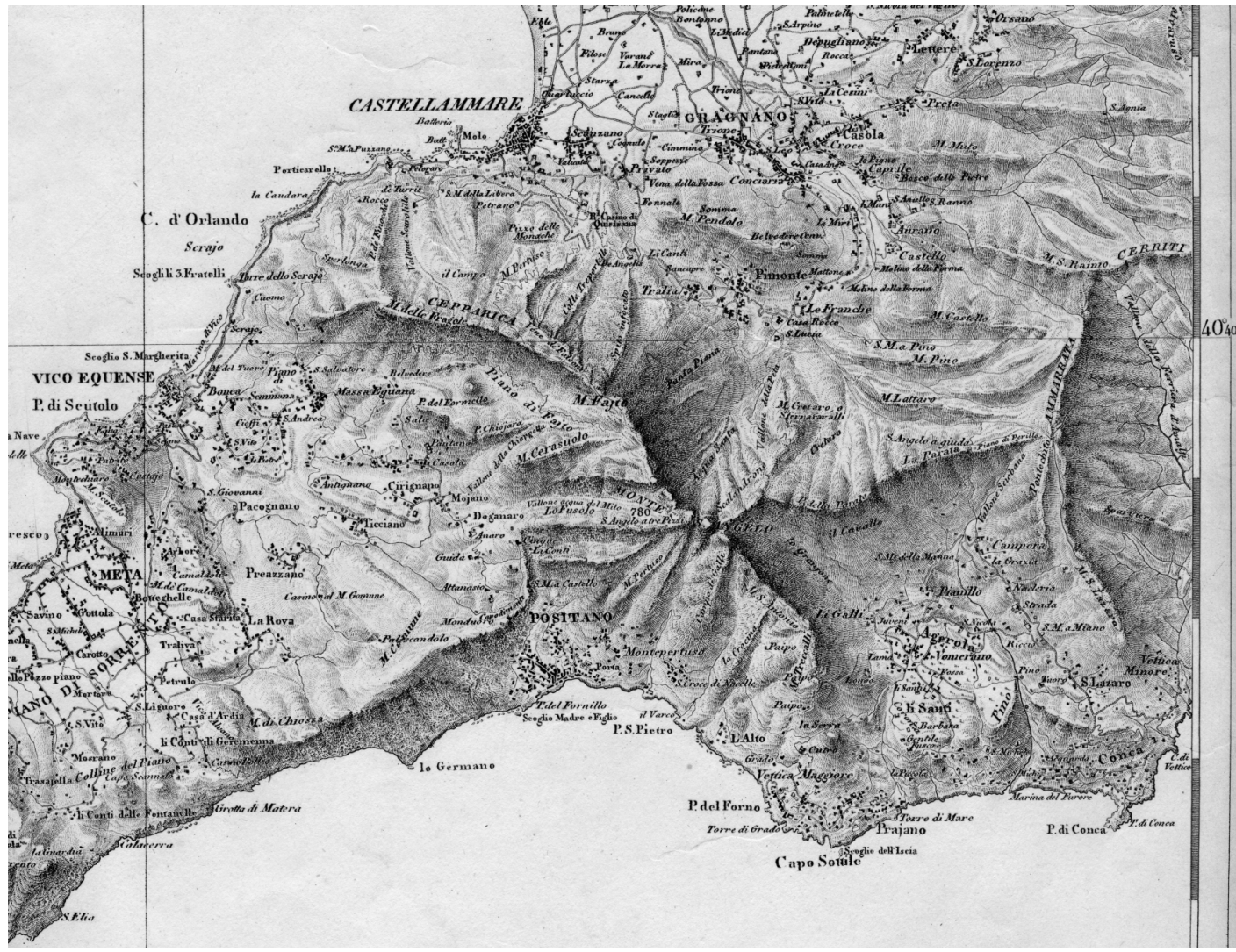

Fig. 5. Detail of the sheet n. 15 of the «Carta dei Contorni di Napoli», scale 1:25000, realized by the Geographer Engeneers Corp of Naples in the years 1817 and 1819 (Private collection).

«[...] conoscerete un fenomeno singolare che colle nostre operazioni abbiamo scoperto» [«[...] you will know a singular phenomenon that we discovered during our geographical operations»]

he wrote to Julian Jackson in June of 1840.

«Un filo a piombo in Palermo - the letter goes on - è deviato dalla verticale per 8 ", e di altrettanto lo $\grave{e}$ a Sciacca, ma in senso contrario» (Visconti, Carteggio, p. 135) $\left(^{6}\right)$ [ $\mathrm{A}$ A plumb in Palermo is deflected from the vertical up to 8 ", and so too it is Sciacca, but in the opposite direction»].

In April 1842, yet in a letter addressed to Julian Jackson, Visconti points out the activities that he is still keeping in mind to do:
«La città di Castellammare a poche miglia da Napoli, è situata a' piedi del Monte S. Angelo bagnato dal mare al north ed al sud, ed alto 3/4 di miglio sul livello del mare. Mi propongo di determinare quanto ed in quale direzione questo monte attrae il filo a piombo, deviandolo dalla verticale» (Visconti, Carteggio, p. 147) [«The town of Castellammare a few miles from Naples, is located at the foot of Mount St. Angelo facing the sea to the north and south, and high 3/4 of a mile above the sea level. I propose to determine how and in what direction this mountain attracts the plumb, deviating from the vertical»] (fig. 5).

But this measurement apparently was never made, nor was the second operation of which he speaks in the same letter to Jackson, April 1842: 
«Sembra che il nostro suolo, specialmente ne' circondarj di Pozzuoli, ov'è assai vulcanico, soffra de' cambiamenti parziali di livello a lunghi tratti di tempo. Voglio dunque con un circolo ripetitore determinare esattamente le differenze di livello tra punti stabilmente marcati e fissati a poca distanza dal mare su tutta l'estensione della costa da Ischia a Procida, lungo il golfo di Pozzuoli, e quello di Napoli fino ad Amalfi, girando per Sorrento, e per la punta della Campanella; e poi far che ogni 10 anni sia ripetuta questa operazione per rilevarne i cennati cambiamenti del nostro suolo» (Visconti, Carteggio, p. 147148) [«It seems that our soil, especially near Pozzuoli, which is a volcanic area, suffers from a partial change of level in long periods of time. It is my intention to determine exactly with a repetition circle the difference in level between points permanently marked and set at short distance from the sea over the whole extent of coast from Ischia to Procida, along the Gulf of Pozzuoli and the one of Naples up to Amalfi, turning to Sorrento and Cape Campanella, and then every 10 years to repeate this operation to detect the changes of our soil»] (figs. 6 and 7).

We are facing the first project of leveling for the assessment of bradyseism, never recorded until then, and that was only partially completed after 1980, following the earthquake and increasing phenomena in Pozzuoli. Furthermore we have to consider that during the years in which Visconti wrote these notes, scientists still debated on the nature of the problem and that rather it was the water levels that varied over the centuries. Among the advocates of the theory of lifting of the earth's crust was the astronomer Ernesto Capocci, who in 1835 published a short pamphlet entitled «Nuove ricerche sul noto fenomeno delle colonne perforate dalla foladi nel tempio di Serapide in Pozzuoli» [«New researches on the well-known phenomenon of the columns perforated by pholas in the temple of Serapis in Pozzuoli»], with which he intended to demonstrate «che veramente il suolo, e non il livello del mare, siasi mosso» [«that really the ground, and not the sea level, moved»].

The friendship and mutual esteem between Visconti and Capocci is attested by numerous documents as well as a certain antagonism, if not genuine antipathy between these men and the Architect Antonio Niccolini, advocate of the opposite assumption. In two of the polemical publications in 1829 and 1839 (Niccolini,
$1829 ; 1939)$, the latter in response to the work by Capocci said in a note, Niccolini said the inability of the movement of soil: «il movimento del suolo - wrote in 1839, giving as closed the question - attribuito alla natura del terreno vulcanico del Cratere sembra chimerico» (Niccolini, 1939, p. 24) [the movement of soil due to the volcanic nature of the soil of the crater appears chimeric»].

Visconti's idea of leveling the Bay of Naples for the study of movements of the ground level was already brought to the attention of the Academy of Sciences of Naples but only in 1842 but he managed to enter these operations among the activities of the Officio Topografico; various commitments, lack of staff and finally the death of Francesco Fergola in 1845 , prevented implemenation of this extraordinary project that would have provided our volcanologists today over 150 years of observations of great quality.

Another story also intertwined lives and works of Visconti and Niccolini and it was the detection of mineral waters on the island of Ischia. This project was initiated by Visconti in agreement with Teodoro Monticelli and the Academy of Sciences of Naples, and for this work former engineers and draftsmen of the Topographical Office were also used: Giovanni Alfaro, already officer of the Neapolitan Staff, removed due to his presence in the rivolts of 1820 , only because the good offices of Visconti was able to work on the behalf of the Academy of Sciences until his return in the military role in 1830 .

Some judgement by Niccolini on the works done by Alfaro and especially the economic assessments of the work performed by him annoyed Visconti who addressed to Teodoro Monticelli in June 1828 as follows:

«Circa gli apprezzi di Niccolini, ed alle pirchierie rustesche poi ne parleremo, e concerteremo perché si ponga in verità il conto de' lavori d'Alfaro» (Visconti, Carteggio, p. 102) [«Around the evaluation of Niccolini, and 'pirchierie rustesche' we'll discuss later and we shall agree to reveal the truth on the work of Alfaro»].

The activities on Ischia took an unexpected turn perhaps inspired by them and led to their expansion and deepening intersecting with the 


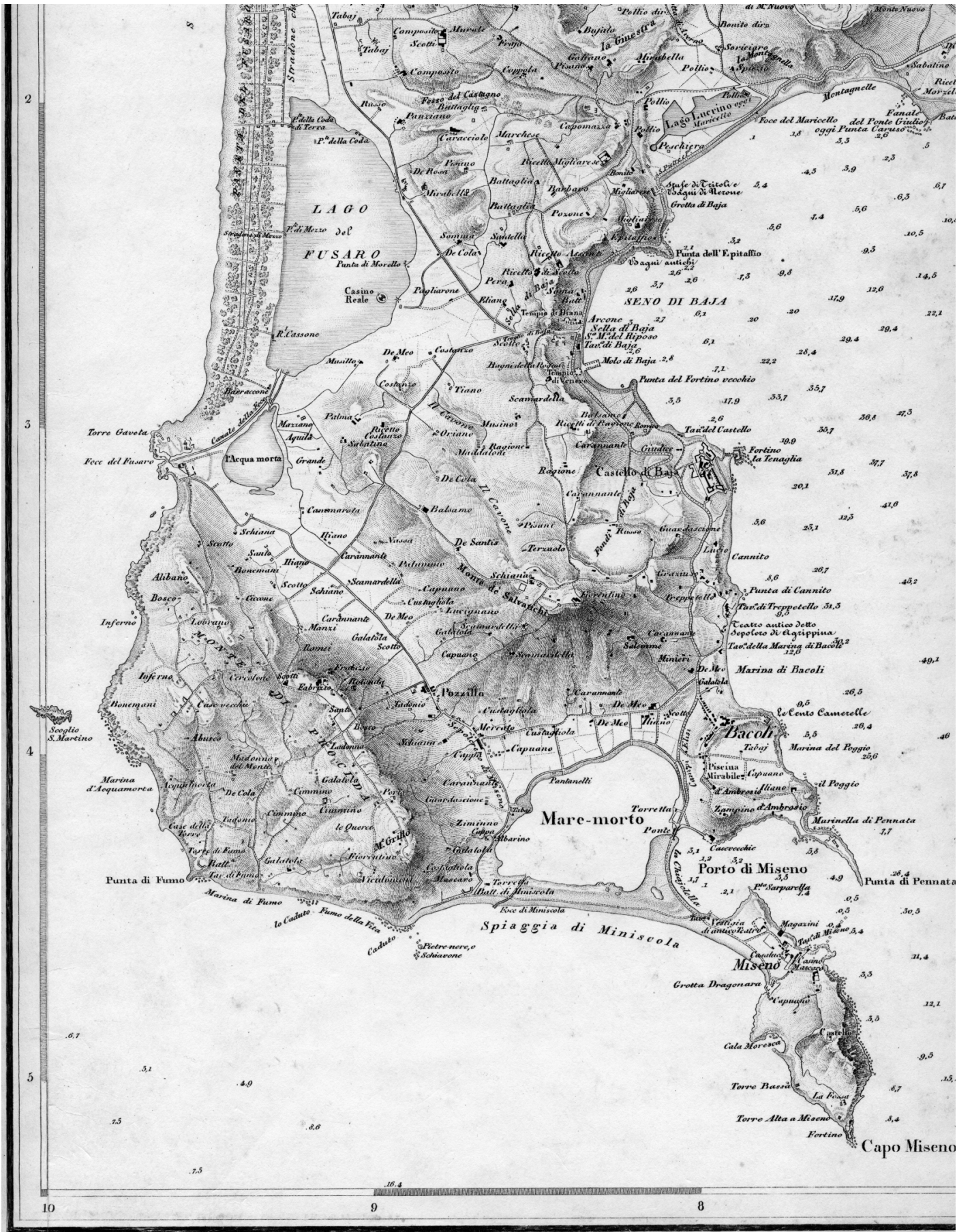

Fig. 6. Detail of the sheet n. 8 of the «Carta dei dintorni di Napoli», scale 1:25000 (Collezione privata). 


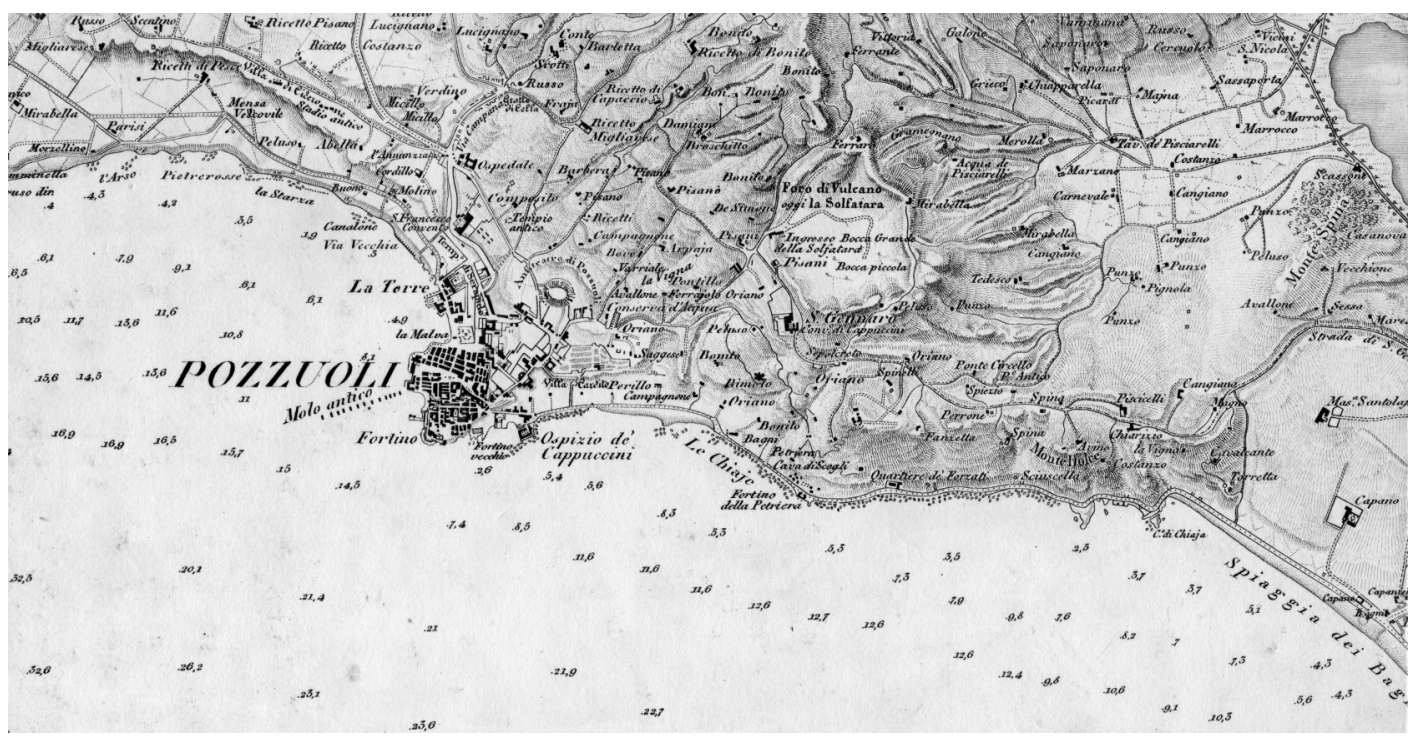

Fig. 7. Detail of the sheet n. 8 of the «Carta dei dintorni di Napoli», scale 1:25000, realized by the Geographer Engeeneers Corp of Naples in the years 1817 and 1819. On this map Visconti planned the levelling operation for studying the Flegraen bradyseism (Private collection).

official topographical surveys carried out for the Great Map of the Kingdom of Naples, as shown in another letter by Visconti to Monticelli in May 1829:

«Il sig.r Frojo $\left(^{7}\right)$ - Visconti writes - si tratterrà pochi giorni in Ischia per levar la pianta del sito di Cartaromana ove sono le acque minerali, e delle vicine coste come anche per riconoscere e disegnare il Monte Campagnano. Di poi passerà a Barano per fissare i siti delle acque di Nitroli e dell'Olmitello, che corre pel burrone dell'Olmitello.

$\mathrm{Su}$ di tutto ha già ricevuto le dovute istruzioni, anche su i lumi che Alfaro ha avuto da Covelli $\left({ }^{8}\right)$ sullo stesso oggetto. Vogliate pertanto far dare le disposizioni perché abbia alloggio comodo a Barano, e tutte le facilitazioni pel suo lavoro, poiché per Ischia il tenente Giordano $\left({ }^{9}\right)$, che colà lavora sotto gli ordini del Brigadiere Tanchi $\left({ }^{10}\right)$ li procurerà ogni facilitazione per Cartaromana» [ «Mr Frojo $\left({ }^{7}\right)$ will stay a few days on Ischia to survey the site of Cartaromana where mineral waters are, and the nearby coast also to recognize and draw Mount Campagnano. Then he will go to Barano to fix the water sites of Nitroli and Olmitello, which runs along Olmitello gully. About everything hi has already received the necessary instructions even on insights that Alfaro had from Cov- elli $\left({ }^{8}\right)$ on the same subject. Please, therefore, give orders for him to have comfortable accommodation in Barano, and all the facilities for his work, since for Ischia Lieutenant Jordan $\left({ }^{9}\right)$, who works there under the orders of Brigadier Tanchi $\left({ }^{10}\right)$ will procure him any help for Cartaromana»].

Five drawings attached to a «risultamento dei lavori chimici sulle acque minerali di Ischia 1827-1828» [«result of the chemical works on mineral waters of Ischia 1827-1828»] are kept in the National Library of Naples (banc. VI, 26/17), which, though not signed, may be assigned to Giovanni Alfaro and his operations mentioned in the Monticelli-Visconti correspondence.

To conclude my brief note, it is noteworthy to mention the project by Visconti to create a Mémorial Topographique, published periodically, similar to that one published for over thirty years in France, giving account of any topographical and geodetic activities undertaken in the Kingdom of Naples.

Visconti submitted the draft to royal approval, but the King was opposed «to the useless expense» and most of the scientific works car- 
ried out and developed in the Officio Topografico of Naples were jealously hidden in the Of- fice's Archive remaining unknown to a much wider and interested public $\left({ }^{11}\right)$.

\section{Notes}

( $\left.{ }^{1}\right)$ His last official biography was published in 1888 in Nuova Enciclopedia Italiana, vol. XXIII, p. 205.

$\left.{ }^{(}\right)$Letter to Sir Francis Beaufort, 27 June 1843, cf. F. Visconti, Carteggio ... , p. 161, 162.

$\left(^{3}\right)$ «... in aprile 1836 ci furono indirizzate da Filadelfia di Pensilvania delle domande del chiarissimo Astronomo Ferdinando Rodolfo Hassler ...» [«... in April 1836 there were sent from Philadelphia in Pennsylvania questions from the Astronomer Ferdinand Rudolph Hassler ...»], see: F. VISCONTI, Del sistema metrico della città di Napoli ..., Napoli 1838, p. 21.

$\left({ }^{4}\right)$ On the geodetic base of Castelvolturno see: V. VALERIO, Società Uomini ..., p. 243 and the bibliography therein stated.

$\left(^{5}\right)$ On these issues, see also P. NASTASI, Il contributo dei geodeti napoletani, pp. 79-92.

$\left.{ }^{(}\right)$The news of the deviation of the plumb in Palermo and Sciacca was published by Francesco Fergola only in 1844.

$\left.{ }^{7}\right)$ This is the topographer Tito Frojo.

$\left({ }^{8}\right)$ Nicola Covelli, professor of chemistry at the University of Naples author, with Teodoro Monticelli of the volume Prodromo della Mineralogia vesuviana Napoli, 1825.

$\left({ }^{9}\right)$ Fridolino Giordano, officer of the Staff and Director of the Officio Topografico of Naples, see: V. VALERIO, Società...., p. 406-408.

$\left({ }^{10}\right)$ Francesco Maria Tanche Director of the Officio Topografico of Palermo between 1812 and 1823, see: V. VALERIO, Società...., p. 419-420.

${ }^{(11)}$ Notice related to the Mémorial was given by Visconti to Jackson in a letter dated 23 October 1838, see: Visconti, Carteggio ..., p. 125.

\section{REFERENCES}

Antologia Militare, (1844): XVIII.

Atti della Reale Accademia delle Scienze di Napoli (1832), pp. 13-36.

Bulletin de la Societé de Géographie (BSG) (1847): VIII, p. 427.

The Journal of the Royal Geographical Society (1848): I, pp. XXXII-XXXIII.

Life, Letters and Journals of Sir Charles Lyell, edited by her sister in law, Mrs Lyell, (London, John Murray) (1881): vol. I, pp. 213.

Nuova Enciclopedia Italiana, vol. XXIII, p. 205.

NASTASI, P. (1985): Il contributo dei geodeti napoletani, in Cartografia Napoletana dal 1781 al 1889, edited by G. Alisio and V. VAlerio, (Prismi, Napoli), pp. 79-92.
NiCCOLINI, A. (1829): Rapporto sulle acque che invadono il pavimento dell'antico edifizio detto il Tempio di Giove Serapide, (Napoli, Stamperia Reale).

NiccolinI, A. (1939): Tavola metrica-cronologica delle varie altezze tracciate dalla superficie del mare fra la costa di Amalfi ed il promontorio di Gaeta nel corso di diciannove secoli, (Napoli, Tipografia Flautina).

VALERIO, V., (1993): Società Uomini e Istituzioni Cartografiche nel Mezzogiorno d'Italia, (Istituto Geografico Militare, Firenze).

VisconTI, F. (1838): Del sistema metrico della città di Napoli e della uniformità de' pesi e delle misure che meglio si conviene a' Reali Dominij di qua dal Faro, (Napoli, Italy), p. 21.

VisconTI, F. (1995): Carteggio (1818-1847), edited by V. VALERIO, (Olschki, Firenze, Italy). 